\title{
Hubungan Pengetahuan dan Sikap Ibu Hamil dengan Kepatuhan dalam Mengkonsumsi Tablet Besi di Wilayah Kerja Puskesmas Seberang Padang Tahun 2013
}

\author{
Rena Regina Erwin ${ }^{1}$, Rizanda Machmud ${ }^{2}$, Bobby Indra Utama ${ }^{3}$
}

\begin{abstract}
Abstrak
Salah satu program pemerintah untuk mencegah anemia kehamilan di Indonesia adalah suplementasi besi yang dibagikan gratis melalui Puskesmas dan Posyandu. Efektifitas program ini sulit dicapai karena sering kali dihambat oleh rendahnya kepatuhan ibu hamil dalam mengkonsumsi tablet besi. Tujuan penelitian ini adalah untuk mengetahui hubungan pengetahuan dan sikap ibu hamil dengan kepatuhan dalam mengkonsumsi tablet besi di wilayah kerja Puskesmas Seberang Padang tahun 2013. Penelitian ini menggunakan desain penelitian cross sectional yang dilakukan pada bulan Januari hingga Oktober 2013. Populasi penelitian adalah seluruh ibu hamil trimester II dan trimester III yang berada di wilayah kerja Puskesmas Seberang Padang, dengan jumlah sampel 52 orang yang diambil dengan menggunakan teknik total sampling. Hasil penelitian diperoleh $79 \%$ ibu hamil termasuk dalam kategori tidak patuh, 58\% ibu hamil dengan pengetahuan kurang, dan $52 \%$ ibu hamil dengan sikap negatif dalam mengkonsumsi tablet besi. Analisis bivariat dengan uji chi-square diketahui bahwa terdapat hubungan yang bermakna antara pengetahuan dan kepatuhan dan juga terdapat hubungan yang bermakna antara sikap dan kepatuhan. Simpulan yang diperoleh dari penelitian ini adalah pengetahuan dan sikap merupakan faktor yang berhubungan dengan kepatuhan ibu hamil dalam mengkonsumsi tablet besi.
\end{abstract}

Kata kunci: kepatuhan, pengetahuan, sikap, ibu hamil, tablet besi

\begin{abstract}
One of the government's program to prevent anemia of pregnancy in Indonesian is iron supplementation which distributed for free through health centers and integrated health. The effectiveness of this program is difficult to achieve because often inhibited by poor adherence of iron tablet consumption in pregnant women. The objective of this study was to determine the correlation of knowledge and attitudes of pregnant women on adherence in of iron tablets consumption at the Seberang Padang Health Center in 2013. This study uses cross-sectional design that conducted from January to October of 2013. The study population was all second and third trimester pregnant women who were in Seberang Padang Health Center working area, with 52 people as sample were taken using total sampling technique. The results showed $79 \%$ of pregnant women are included in the category of non-adherence, $58 \%$ of pregnant women with less knowledge, and $52 \%$ of pregnant women with a negative attitude in consuming iron tablets. Bivariate analysis by chi-square test was a significant relation between knowledge and adherence, also a significant relation between attitudes and adherence. The conclusion is the knowledge and attitude are factors associated on adherence of iron tablet consumptoin in pregnant women.
\end{abstract}

Keywords: adherence, knowledge, attitude, pregnant women, iron tablet

Affiliasi penulis: 1. Prodi Profesi Dokter FK Unand (Fakultas Kedokteran Universitas Andalas Padang), 2. Bagian IImu Kesehatan Masyarakat FK Unand, 3. Bagian Obstetri dan Ginekologi FK Unand
Korespondensi: Rena Regina Erwin Email: renareginaerwin@yahoo.com Telp: 085979800004 


\section{PENDAHULUAN}

Kesehatan ibu dan anak mendapat perhatian besar dari negara di dunia sehingga dimasukkan ke dalam deretan delapan tujuan MDGs (Millennium Development Goals) yang harus dicapai pada tahun 2015. MDGs adalah suatu rancangan pembangunan milenium oleh 191 negara termasuk Indonesia yang bertujuan untuk menghapuskan tingkat kemiskinan dan kelaparan, mencapai pendidikan dasar secara universal, mendorong kesejahteraan gender dan pemberdayaan perempuan, mengurangi tingkat kematian anak, meningkatkan kesehatan ibu, memerangi HIVIAIDS (Human Immunodeficiency Virus/ Acquired Immunodeficiency Syndrome), malaria, dan penyakit lainnya, menjamin kelestarian lingkungan hidup, serta membangun kemitraan global dalam pembangunan. ${ }^{1}$

Di kota Padang, kejadian anemia kehamilan meningkat dari $7.32 \%$ pada tahun 2009 menjadi $24.5 \%$ pada tahun $2011^{2,3}$

Pada saat kehamilan, kebutuhan oksigen meningkat sehingga produksi eritropoitin di ginjal juga meningkat. Akibatnya, sel darah merah (eritrosit) meningkat sebanyak $20-30 \%$. Namun peningkatan ini tidak sebanding dengan penambahan volume plasma yang progresif, yaitu sebesar $40-45 \%$, sehingga terjadi proses hemodilusi (pengenceran darah) yang menyebabkan penurunan konsentrasi $\mathrm{Hb} .{ }^{4}$ Oleh sebab itu, resiko anemia meningkat bersama dengan kehamilan, sehingga ibu hamil membutuhkan zat besi dua kali lipat guna memenuhi kebutuhan ibu dan pertumbuhan janin. ${ }^{5}$

Salah satu upaya untuk mencapai tujuan keempat dan kelima MDGs pada tahun 2015 yaitu mengurangi tingkat kematian anak dan meningkatkan kesehatan ibu adalah dengan cara mencegah terjadinya anemia dalam kehamilan terutama anemia defisiensi zat besi. Pencegahan dapat dilakukan dengan mencukupi kebutuhan nutrisi selama kehamilan. Salah satu program pemerintah di Indonesia untuk mencegah anemia kehamilan adalah suplementasi besi yang dibagikan gratis melalui Puskesmas dan Posyandu dengan mendistribusikan tablet besi yang mengandung $60 \mathrm{mg}$ elemental besi minimal 90 hari selama kehamilan. ${ }^{6}$
Efektifitas program ini dapat dicapai bila semua ibu hamil yang telah mendapat suplementasi besi harus menjaga kepatuhan dalam mengkonsumsinya. Kepatuhan ibu hamil dalam mengkonsumsi tablet besi di Indonesia masih rendah. Kepatuhan adalah istilah yang digunakan untuk menjelaskan ketaatan pada tujuan yang telah ditentukan. ${ }^{7}$ WHO dalam Kalogianni membagi faktor yang mempengaruhi kepatuhan dalam pengobatan secara umum menjadi 5 dimensi yaitu, social economic terkait status sosial ekonomi pasien, patient related seperti kurangnya pengetahuan pasien, therapy related mengenai durasi pengobatan yang lama, condition related seperti hilangnya gejala yang dirasakan membuat pasien menghentikan pengobatan, dan health care system yang terkait dengan komunikasi antara pasien dan tenaga kesehatan. $^{8}$

Pengetahuan merupakan salah satu faktor yang berpengaruh dalam kepatuhan ibu hamil. Menurut Rahmawati dan Subagio, ketidakpatuhan ibu hamil dalam mengkonsumsi tablet besi sesuai anjuran petugas kesehatan merupakan suatu dampak dari ketidaktahuan mereka tentang pentingnya asupan zat besi yang cukup saat kehamilan. ${ }^{9}$ Selain pengetahuan, faktor lain yang sangat memegang peranan penting dalam kepatuhan adalah sikap ibu hamil. Ibu hamil yang memiliki sikap yang baik akan mengerti bahwa pentingnya memeriksakan kehamilan ke pelayanan kesehatan dan mengkonsumsi tablet besi. ${ }^{10}$

Berdasarkan penelitian di Puskesmas Halmahera Kota Semarang, terdapat hubungan yang bermakna antara pengetahuan, sikap, dan motivasi dengan kepatuhan ibu hamil dalam mengkonsumsi tablet besi. ${ }^{10}$ Oleh karena itu, peneliti tertarik untuk melakukan penelitian yang sama di Kota Padang, tetapi hanya menggunakan dua variabel independen yaitu sikap dan pengetahuan.

Penelitian akan dilakukan di Puskesmas Seberang Padang karena wilayah ini merupakan salah satu daerah dengan angka kejadian anemia kehamilan tinggi di Kota Padang dan terus meningkat selama tiga tahun berturut-turut, yaitu sebesar $14.44 \%$ pada tahun 2009 , sebesar $28.6 \%$ pada tahun 2010 , dan sebesar $43.1 \%$ pada tahun 2011 . $^{2,3}$ 


\section{METODE}

Penelitian yang dilakukan adalah jenis penelitian analitik observasional dengan desain cross sectional, yaitu pengukuran variabel yang dilakukan pada suatu saat tertentu. Penelitian ini dilakukan di wilayah kerja Puskesmas Seberang Padang pada bulan Januari 2013 sampai dengan Oktober 2013. Populasi penelitian adalah seluruh ibu hamil trimester II dan trimester III yang berada di wilayah kerja Puskesmas Seberang Padang. Penelitian ini menggunakan teknik total sampling, yaitu seluruh populasi dijadikan sampel.

HASIL

\section{Kepatuhan}

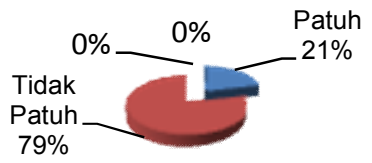

Gambar 1. Gambaran karakteristik kepatuhan ibu hamil dalam mengkonsumsi tablet besi di wilayah kerja Puskesmas Seberang Padang tahun 2013

Gambar 1 menunjukkan bahwa dari 52 orang ibu hamil yang patuh mengkonsumsi tablet besi sesuai anjuran petugas kesehatan hanya 11 orang (21\%), sedangkan yang tidak patuh sebanyak 41 orang (79\%).

\section{Pengetahuan}

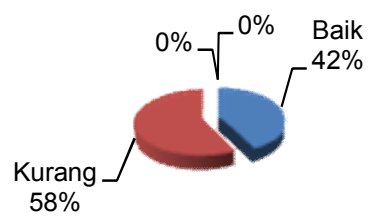

Gambar 2. Gambaran karakteristik pengetahuan ibu hamil mengenai zat besi di wilayah kerja Puskesmas Seberang Padang tahun 2013.
Gambar 2 menggambarkan bahwa dari 52 orang responden, ibu hamil yang memiliki pengetahuan baik adalah sebanyak 22 orang (42\%) dan yang memiliki pengetahuan kurang adalah sebanyak 30 orang $(58 \%)$.

\section{Sikap}

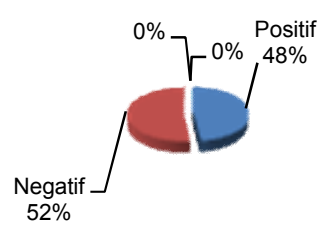

Gambar 3. Gambaran karakteristik sikap ibu hamil dalam mengkonsumsi tablet besi di wilayah kerja Puskesmas Seberang Padang Tahun 2013.

Pada Gambar 3 dapat dilihat bahwa 25 orang responden (48\%) memiliki sikap positif dan 27 orang (52\%) memiliki sikap negatif dalam mengkonsumsi tablet besi.

Tabel 1. Hubungan pengetahuan dan kepatuhan ibu hamil.

\begin{tabular}{ccccccc}
\hline PENGETAHUAN & \multicolumn{5}{c}{ KEPATUHAN } & \multirow{2}{*}{ OR } \\
\cline { 2 - 5 } & Patuh & $\%$ & $\begin{array}{r}\text { Tidak } \\
\text { Patuh }\end{array}$ & $\%$ & & P \\
\hline Baik & 8 & 36.4 & 14 & 63.6 & & \\
Kurang & 3 & 10.0 & 27 & 90 & 0,021 & 5.143 \\
TOTAL & 11 & 21.2 & 41 & 78.8 & & \\
\hline
\end{tabular}

Berdasarkan Tabel 1 dapat dilihat bahwa ibu hamil yang patuh lebih banyak ditemukan pada responden dengan pengetahuan baik (36.4\%) dibandingkan responden dengan pengetahuan kurang (10.0\%). Nilai $p$ yang didapat adalah sebesar 0.021 $(p<0.05)$ yang berarti bahwa terdapat hubungan yang bermakna antara pengetahuan dan kepatuhan ibu hamil. Hasil analisis keeratan hubungan menunjukan nilai Odd Ratio (OR) 5.143 yang berarti bahwa responden yang memiliki pengetahuan baik 5.143 kali lebih patuh dalam mengkonsumsi tablet besi dibandingkan dengan responden yang memiliki pengetahuan kurang. 
Tabel 2. Hubungan sikap dan kepatuhan ibu hamil.

\begin{tabular}{ccccccc}
\hline & \multicolumn{5}{c}{ KEPATUHAN } & \\
\cline { 2 - 5 } SIKAP & Patuh & $\%$ & $\begin{array}{r}\text { Tidak } \\
\text { Patuh }\end{array}$ & $\%$ & & OR \\
\hline Positif & 10 & 40.4 & 15 & 60.0 & 0,001 & 17.333 \\
Negatif & 1 & 3.7 & 26 & 96.3 & & \\
TOTAL & 11 & 21.2 & 41 & 78.8 & \\
\hline
\end{tabular}

Tabel 2 menggambarkan bahwa responden yang memiliki sikap positif lebih patuh mengkonsumsi tablet besi (40.4\%) dibandingkan dengan responden yang memiliki sikap negatif (3.7\%). Berdasarkan uji statistik, nilai $p$ yang didapat adalah sebesar 0,001 $(p<0.05)$ yang berarti bahwa terdapat hubungan yang bermakna antara sikap dan kepatuhan ibu hamil. Hasil analisis didapat menunjukan nilai Odd Ratio (OR) 17.333 yang berarti bahwa responden yang memiliki sikap positif berpeluang 17.333 kali lebih patuh dalam mengkonsumsi tablet besi dibandingkan dengan responden yang memiliki sikap negatif.

\section{PEMBAHASAN}

\section{Kepatuhan Ibu Hamil dalam Mengkonsumsi Tablet} Besi

Kepatuhan ibu hamil dalam mengkonsumsi tablet besi didefinisikan sebagai ketaatan ibu hamil untuk mengkonsumsi tablet besi selama kehamilan sesuai dengan anjuran petugas kesehatan. Di Indonesia, program pemeritah mengharuskan ibu hamil untuk mengkonsumsi tablet besi 1 tablet sehari minimal 90 tablet dalam 90 hari selama kehamilan. ${ }^{11}$

Berdasarkan hasil penelitian pada Gambar 1, dari 52 responden didapatkan lebih dari setengah ibu hamil $(79 \%)$ tidak patuh dalam mengkonsumsi tablet besi. Hasil penelitian ini sesuai dengan penelitian yang sudah dilakukan sebelumnya, salah satunya penelitian Rahmawati dan Subagio di Puskesmas Halmahera pada tahun 2012 dengan desain penelitian cross sectional yang menunjukkan persentase ibu hamil yang tidak patuh (58.9\%) lebih besar dari yang patuh. ${ }^{9}$

Distribusi tablet besi di Kota Padang pada umumnya sudah baik. Begitu pula di wilayah kerja Puskesmas Seberang Padang. Berdasarkan Laporan Tahunan Puskesmas Seberang Padang tahun 2012, cakupan pembagian tablet besi pada di wilayah tersebut sudah mencapai $92 \%$, tetapi angka tersebut tidak sejalan dengan kejadian anemia yang masih meningkat setiap tahun. Hal tersebut dapat terjadi karena kepatuhan ibu hamil dalam mengkonsumsi tablet besi di wilayah kerja Puskesmas Seberang Padang yang masih tergolong rendah $(21 \%)$.

Tujuan pemerintah di Indonesia mengadakan program suplementasi besi adalah untuk mencegah terjadinya anemia kehamilan. Zat besi yang diserap dari makanan tidak cukup untuk memenuhi kebutuhan ibu dan janin, sehingga perlu asupan besi tambahan yang diberikan melalui tablet besi. ${ }^{12}$ Namun efektifitas program ini seringkali dihambat oleh kepatuhan ibu hamil. Ibu hamil yang tidak patuh dalam mengkonsumsi tablet besi berarti tidak mampu mencukupi kebutuhan zat besi dalam kehamilan. Akibatnya, resiko terjadinya anemia kehamilan terutama anemia defisiensi besi semakin meningkat. Anemia secara tidak langsung dapat menyebabkan kematian maternal. Ibu dengan anemia beresiko untuk mengalami perdarahan postpartum dan melahirkan bayi prematur atau bayi dengan berat lahir rendah. ${ }^{12}$

Peningkatan kepatuhan ibu hamil perlu diketahui terlebih dahulu faktor-faktor yang berhubungan dengan kepatuhan ibu hamil dalam mengkonsumsi tablet besi, diantaranya adalah pengetahuan dan sikap ibu hamil yang merupakan variabel independen dalam penelitian ini.

\section{Hubungan Pengetahuan dan Kepatuhan Ibu Hamil}

Hasil uji statistik chi-square pada Tabel 1 diperoleh nilai $p$ sebesar $0,021(p<0.05)$. Berdasarkan hasil tersebut dapat disimpulkan bahwa secara statistik terdapat hubungan yang bermakna antara pengetahuan dan kepatuhan ibu hamil dalam mengkonsumsi tablet besi di wilayah kerja Puskesmas Seberang Padang.

Hasil penelitian ini sejalan dengan penelitian yang dilakukan di Kabupaten Banyumas dengan desain penelitian cross sectional yang menunjukkan hasil yang serupa bahwa pengetahuan merupakan salah satu faktor yang berhubungan dengan kepatuhan ibu hamil dalam mengkonsumsi tablet besi. $^{6}$

Menurut penelitian ${ }^{9}$, ketidakpatuhan ibu hamil dalam mengkonsumsi tablet besi sesuai anjuran petugas kesehatan merupakan suatu dampak dari 
ketidaktahuan mereka tentang pentingnya asupan zat besi yang cukup selama kehamilan. Pengetahuan yang dimiliki oleh ibu hamil akan berpengaruh terhadap perilakunya. Ibu hamil dengan pengetahuan gizi yang baik akan berusaha memberikan gizi yang cukup pula untuk diri sendiri dan janinnya. Pengetahuan ibu hamil mengenai zat besi akan berdampak pada sikap terhadap pangan dengan menerapkan informasi yang didapat dalam menyediakan makanan yang mengandung sumber zat besi untuk memenuhi kebutuhan selama kehamilan. ${ }^{13}$

Pengetahuan merupakan salah satu faktor penting untuk membentuk suatu sikap yang utuh. Semakin baik pengetahuan seseorang semakin baik sikap yang akan terbentuk untuk menciptakan suatu tindakan yang baik pula. Ibu hamil dengan pengetahuan yang baik mengenai pentingnya zat besi dan akibat yang ditimbulkan apabila kekurangan zat besi dalam kehamilan akan cenderung membentuk sikap yang positif terhadap kepatuhan sehingga timbul tindakan patuh dalam mengkonsumsi tablet besi. ${ }^{14}$

Hasil penelitian menunjukkan bahwa kepatuhan ibu hamil dalam mengkonsumsi di wilayah kerja Puskesmas Seberang Padang yang masih rendah dapat disebabkan karena masih banyak ibu hamil yang memiliki pengetahuan kurang mengenai zat besi. Akibatnya, kesadaran ibu hamil untuk mengkonsumsi tablet besi juga masih rendah. Hal ini yang menjadi salah satu penyebab masih meningkatnya angka kejadian anemia. Pengetahuan mengenai kebutuhan zat besi, manfaat zat besi, sumber makanan yang mengandung zat besi, akibat yang ditimbulkan apabila kekurangan zat besi, dan informasi lainnya dapat diperoleh ibu melalui penyuluhan yang diberikan petugas kesehatan dalam kunjungan ANC.

\section{Hubungan Sikap dan Kepatuhan Ibu Hamil}

Uji statistik chi-square pada Tabel 2 diperoleh nilai $p$ sebesar $0,001 \quad(p<0.05)$. Berdasarkan hasil tersebut dapat disimpulkan bahwa secara statistik, terdapat hubungan yang bermakna antara sikap dan kepatuhan ibu hamil dalam mengkonsumsi tablet besi di wilayah kerja Puskesmas Seberang Padang.

Hasil penelitian ini sesuai dengan beberapa penelitian yang sudah dilakukan sebelumnya, yaitu penelitian yang dilakukan ${ }^{15}$ di Kabupaten Demak dengan desain penelitian cross sectional yang menunjukkan bahwa terdapat hubungan yang signifikan antara sikap dan kepatuhan ibu hamil dalam mengkonsumsi tablet besi. ${ }^{15}$ Begitu pula hasil yang didapat dari penelitian Budiarni dan Subagio pada tahun $2012 .^{10}$

Menurut teori yang dijelaskan oleh Mar'at ${ }^{16}$, sikap terdiri atas 3 komponen penting yang saling berhubungan satu sama lain. Komponen pembentuk struktur sikap yaitu komponen kognitif (komponen perceptual) yang berisi dengan kepercayaan, keyakinan, pengetahuan, dan pengalaman pribadi seseorang, komponen afektif (emosional) yang berhubungan dengan kemampuan seseorang untuk menilai suatu objek, dan komponen konatif (komponen perilaku) yang berkaitan dengan kecenderungan untuk bertindak. Sikap merupakan suatu predisposisi untuk terbentuknya suatu tindakan. Ibu hamil yang memiliki sikap positif akan cencerung bertindak patuh dalam mengkonsumsi tablet besi, sebaliknya ibu hamil yang memiliki sikap negatif akan cenderung bertindak tidak patuh dalam mengkonsumsi tablet besi selama kehamilan.

Hasil penelitian didapatkan lebih dari setengah responden masih bersikap negatif dalam mengkonsumsi tablet besi. Sikap yang negatif dapat menciptakan tindakan yang tidak patuh sehingga kepatuhan ibu hamil dalam mengkonsumsi tablet besi di wilayah kerja Puskesmas Seberang Padang masih tergolong rendah. Akibatnya, efektifitas program pemerintah dalam mencegah anemia kehamilan akan sulit dicapai terutama di wilayah ini.

\section{SIMPULAN}

Pengetahuan berhubungan dengan kepatuhan ibu hamil dalam mengkonsumsi tablet besi. Sikap berhubungan dengan kepatuhan ibu hamil dalam mengkonsumsi tablet besi.

\section{UCAPAN TERIMA KASIH}

Terimakasih kepada semua pihak atas bimbingan, bantuan, dan motivasi dalam penelitian ini. 


\section{DAFTAR PUSTAKA}

1. World Health Organization (WHO). Millennium development goals. 2013 (diunduh 26 April 2013).

Tersedia dari: URL: HYPERLINK http://www.who.int/topics/millennium development goals/about/en/index.html tanggal 26 April 2013.

2. Dinas Kesehatan Kota Padang. Laporan tahunan kesehatan ibu dan anak (KIA) 2009. Padang; 2010.

3. Dinas Kesehatan Kota Padang. Laporan tahunan kesehatan ibu dan anak (KIA) 2011. Padang; 2012.

4. Prawirohardjo S. IImu kebidanan, Edisi ke-4. Jakarta: PT Bina Pustaka Sarwono Prawirohardjo; 2009.

5. Cunningham FG, Gant NF, Leveno KJ, Glistrap LC, Hauth JC, Wenstrom KD, editor (penyuntuing). Kelainan hematologis. Obstetri Williams. Edisi ke21., Vol 2. Jakarta: EGC; 2006. hlm .14.

6. Ramawati D, Saryono, Puspitasari FD. Faktorfaktor yang mempengaruhi kepatuhan ibu hamil dalam mengkonsumsi tablet besi di Desa Sokaraja Tengah, Kecamatan Sokaraja, Kabupaten Banyumas. JKS. 2008;3(3).

7. Bastable S. Perawat sebagai pendidik: prinsipprinsip pengajaran dan pembelajaran. Jakarta: EGC; 2008.

8. Kalogianni A. Factors affect in patient adherence to medication regimen. Health Science Journal. 2011; 5:157-8.

9. Rahmawati F, Subagio HW. Compliance of iron folate tablets consumption in pregnant women at Puskesmas Halmahera and The factors influenced. JNC. 2012;1(1):111-24.

10. Budiarni W, Subagio HW. Hubungan pengetahuan, sikap, dan motivasi dengan kepatuhan konsumsi tablet besi folat pada ibu hamil. JNC. 2012;1(1): 269-82.

11. Susiloningtyas I. Pemberian zat besi (Fe) dalam kehamilan. Majalah IImiah Sultan Agung. 2012; 50(128).

12. Afnita d. hubungan perilaku ibu hamil dan motivasi petugas kesehatan dengan kepatuhan dalam mengkonsumsi tablet besi pada ibu hamil Di Rumah Sakit Ibu dan Anak BADRUL AINI Medan tahun 2004 (skripsi). Medan: FKM Universitas Sumatera Utara; 2004.

13. Proverawati A, Asfuah S. Buku ajar gizi untuk kebidanan. Yogyakarta: Nuha Medika; 2009.

14. Sunaryo. Psikologi untuk keperawatan. Jakarta: EGC; 2004.

15. Rianika I. Hubungan pengetahuan dan sikap ibu hamil tentang tablet zat besi dengan kepatuhan ibu hamil dalam konsumsi tablet zat besi di wilayah kerja Puskesmas Karangawen II Desa Tlogorejo Karangawen Demak (skripsi). Semarang: Fakultas Keperawatan Universitas Muhammadiyah Semarang; 2009.

16. Mar'at. Sikap manusia: perubahan serta pengukurannya. Jakarta: Ghalia Indonesia; 1984. 